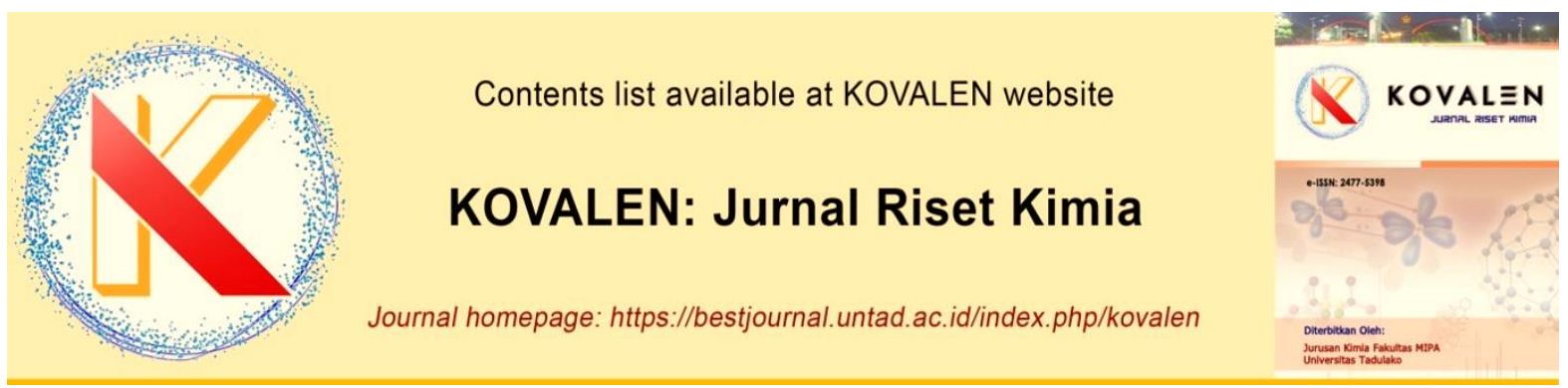

\title{
Karakterisasi Simplisia dan Uji Aktivitas Antioksidan Ekstrak dan Fraksi Daun Pidada Merah (Sonneratia caseolaris L)
}

\section{[Characterization and Evaluation of Antioxidant Activity of Red Pidada Leaves (Sonneratia caseolaris L)]}

\author{
Eka Siswanto Syamsul*, Supomo, Siti Jubaidah \\ Sekolah Tinggi Ilmu Kesehatan Samarinda \\ Jl. A. Wahab Sjahranie No.226 Samarinda, Kalimantan Timur \\ *Corresponding author: eka8382@gmail.com
}

\begin{abstract}
Research on red Pidada leaves (Sonneratia caseolaris L.) which is a mangrove plant with antioxidant potential has been carried out. This study aims to determine the simplicia characterization and activity of red Pidada leaf extracts and fractions as antioxidants. The results of the simplicia characterization were: water-soluble extract content of $11 \%$, ethanol-soluble extract content of $16 \%$, water content of $9 \%$, ash content of $8.17 \%$, and acid insoluble ash content of $0.48 \%$. The antioxidant activity test was carried out using the DPPH (1,1-diphenyl-2picrylhydrazyl) method. The antioxidant activity was determined by the $\mathrm{IC}_{50}$ (Inhibition Concentration) value. The results showed that the ethanol extract had an $\mathrm{IC}_{50}$ value of $24.22 \mathrm{ppm}$ (very strong), n-hexane fraction $88.18 \mathrm{ppm}$ (strong), ethyl acetate fraction 15.39 ppm (very strong), and ethanol fraction 38.41 ppm (very strong)
\end{abstract}

Keywords: Sonneratia caseolaris L., antioxidants, $D P P H, I C_{50}$

ABSTRAK. Telah dilakukan penelitian daun pidada merah (Sonneratia caseolaris L.) yang merupakan tanaman mangrove yang berpotensi antioksidan Tujuan penelitian untuk mengetahui karakterisasi simplisia dan aktivitas ekstrak dan fraksi daun pidada merah sebagai antioksidan. Hasil karakterisasi simplisia yaitu: kadar sari larut air $11 \%$, kadar sari larut etanol 16\%, kadar air 9\%, kadar abu 8,17\%, dan Kadar abu tidak larut asam 0,48\%. Uji aktivitas antioksidan dilakukan dengan metode DPPH (1,1-difenil-2-pikrilhidrazi). Aktivitas antioksidan ditentukan nilai $I C_{50}$. Hasil penelitian menunjukkan bahwa ekstrak etanol memiliki nilai $I C_{50} 24,22$ ppm (sangat kuat), fraksi nheksana 88,18 ppm (kuat), fraksi etil asetat 15,39 ppm (sangat kuat), dan fraksi etanol 38,41 ppm (sangat kuat)

Kata Kunci: Sonneratia caseolaris L., antioksidan, $D P P H, I C_{50}$

Riwayat artikel: Diterima 2 November 2020, Disetujui 26 November 2020

Cara sitasi: Syamsul, E S., Supomo., \& Jubaidah, S. (2020). Karakterisasi Simplisia dan Uji Aktivitas Antioksidan Ekstrak dan Fraksi Daun Pidada Merah (Sonneratia caseolaris L). KOVALEN: Jurnal Riset Kimia, 6(3): 184-190.

DOI: https://doi.org/10.22487/kovalen.2020.v6.i3.15319

\section{LATAR BELAKANG}

Pidada Merah (Sonneratia caseolaris L.) adalah merupakan tanaman mangrove. Masyarakat banyak menggunakan rambai laut sebagai obat tradisional khususnya di Kalimantan Selatan, buah dan daun rambai laut ini sering dijadikan obat serta bahan ramuan bedak dingin dan penghilang bekas luka (Sadhu et al., 2006). Selain itu bagian buah, kulit kayu dan daun dari spesies Sonneratia telah digunakan dalam obat tradisional untuk mengobati sakit asma, obat penurun panas, bisul, hepatitis, keseleo, ambeien dan pendarahan (Nurmalasari et al., 2016). 
Tumbuhan ini dapat dimanfaatkan untuk bahan makanan, daunnya yang masih muda dapat diolah menjadi makanan dan campuran masakan, dan buahnya yang sudah tua dapat dimanfaatkan sebagai minuman, dan kayu dari pohon rambai laut dapat dimanfaatkan sebagai kayu bakar. Tumbuhan pidada yang secara tradisional digunakan sebagai ramuan bedak dingin (Wijaya et al., 2018). Penelitian yang telah dilakukan oleh (Suprianto \& M, 2016) bahwa tumbuhan ini mengandung senyawa alkaloid, flavonoid, glikosida, saponin dan fenol. Hal ini sesuai dengan penelitian yang dilakukan oleh (Avenido \& Serrano Jr, 2012) ekstrak Pidada Merah memiliki aktivitas antioksidan yang sangat kuat sebesar 21,62 ppm karena memiliki metabolit sekunder yang merupakan salah satu bahan obat dan memiliki struktur molekul serta memiliki aktivitas biologi yang beraneka ragam. Hasil isolasi daun Pidada Merah mengandung senyawa asam lemak, sterol hidrokarbon, dan dua flavonoid yaitu luteolin dan luteolin $7-O-\beta$ glukosida yang memiliki daya antioksidan yang tinggi (Sadhu et al., 2006; Sosio et al., 2014).

Penelitian yang dilakukan oleh (Jubaidah et al., 2019) diketahui bahwa fraksi polar daun Sonneratia caseolaris $\mathrm{L}$ memiliki kadar fenolik total sebesar $213,49 \pm 1,223 \mathrm{mg} \mathrm{GAE} / \mathrm{g}$ yang artinya dalam setiap gram fraksi polar setara dengan 213,49 mg asam galat, sedangkan pada fraksi nonpolar daun rambai laut diperoleh sebesar 55,79 $\pm 1,081 \mathrm{mg} \mathrm{GAE} / \mathrm{g}$ yang artinya dalam setiap gram fraksi nonpolar setara dengan $55,79 \mathrm{mg}$ asam galat. Kadar fenolik total yang di hasilkan lebih besar pada fraksi yang polar. Senyawa fenolik yang terdapat didalam tumbuhan berfungsi melindungi jaringan tanaman terhadap kerusakan akibat radiasi sinar matahari. Senyawa fenolik pada flavonoid punya potensi kuat untuk antioksidan karena adanya gugus kromofor yang mampu menangkap radikal bebas. Tujuannya untuk mengetahui karakterisasi simplisia dan aktivitas ekstrak dan fraksi daun pidada merah sebagai antioksidan.

\section{METODE PENELITIAN}

\section{Bahan dan Peralatan}

Sampel yang digunakan dalam penelitian ini adalah daun Pidada Merah (Sonneratia caseolaris L.) yang diperoleh dari daerah Samboja Kabupaten Kutai Kartanegara Kalimantan Timur. Waktu panen diambil pada sore hari bertujuan agar proses fotosintesis pada tumbuhan telah sempurna. Bahan lainnya berupa etanol $70 \%$, vitamin C, DPPH (1,1-difenil-2-pikrilhidrazil), air suling, serbuk Mg, Besi (III) Klorida, amil alkohol, asam klorida $2 \mathrm{~N}$, pereaksi Bouchardat, pereaksi Dragendrof dan pereaksi Mayer.

Alat yang digunakan pada penelitian berupa seperangkat alat maserasi, alat gelas, kertas saring, corong kaca, botol vial, kuvet, kaca arloji, sarung tangan, cawan porselen, timbangan analitik, blender, aluminium foil, ayakan mesh 60 , batang pengaduk, mikropipet dan Spektrofotometri UV-Vis (Shimadzu UV-1800).

\section{Prosedur Penelitian}

\section{Determinasi tanaman}

Determinasi bertujuan untuk memastikan kebenaran tumbuhan yang diteliti dan untuk menghindari terjadinya kesalahan dalam pengambilan bahan penelitian serta proses dalam menentukan nama dan jenis tumbuhan secara spesifik. Determinasi tumbuhan yang dilakukan di Balai Besar Konservasi Sumber Daya Alam Samboja Kalimantan Timur.

\section{Pembuatan simplisia}

Daun Pidada Merah yang telah dikumpulkan lalu dipisahkan dari kotoran yang 
melekat. Dicuci dengan air bersih dan mengalir. Dirajang dan dikeringkan dengan cara diangin-anginkan di tempat yang teduh, proses pengeringan dilakukan kurang lebih selama 1 minggu. Simplisia kering ditimbang kemudiaan dihaluskan hingga menjadi serbuk dan diayak menggunakan ayakan mesh 60 . Pengayakan dengan mesh 60 bertujuan untuk memperkecil ukuran serbuk dan memperluas permukaan serbuk

\section{Karakterisasi daun pidada merah (Sonneratia caseolaris L.)}

Meliputi pemeriksaan parameter spesifik yaitu: Makroskopik. Mikroskopik, pemeriksaan kadar simplisia (kadar sari larut air dan etanol) dan parameter non spesifik yaitu kadar air, kadar abu dan Kadar abu tidak larut asam.

\section{Ekstraksi dan fraksinasi daun pidada merah (Sonneratia caseolaris L.)}

Metode ekstraksi yang digunakan adalah metode maserasi, metode ini merupakan metode ekstraksi yang sederhana. Metode maserasi dipilih karena memperkecil kemungkinan terjadinya kerusakan pada senyawa yang terdapat pada sampel akibat proses pemanasan. Pelarut yang digunakan dalam proses ekstraksi adalah etanol $70 \%$. Etanol $70 \%$ semipolar sehingga menghasilkan jumlah bahan aktif yang optimal.

Ekstrak etanol difraksinasi secara bertingkat dengan metode fraksinasi cair-cair menggunakan pelarut n-heksana dan etil asetat Ekstrak etanol dilarutkan dengan aquades kemudian ditambahkan pelarut $n$ heksana dan dilakukan penggojogan/ pemisahan menggunakan prosedur corong pisah. Setelah itu, didiamkan beberapa saat hingga terbentuk dua lapisan yaitu lapisan nheksana (lapisan atas) dan lapisan air (lapisan bawah). Selanjutnya fraksi n-heksana dipisahkan dan ditampung untuk diuapkan pelarutnya, sedangkan fraksi air dimasukkan kembali kedalam corong pisah untuk dilanjutkan pada proses fraksinasi berikutnya. Untuk mendapatkan fraksi etil asetat dan fraksi etanol (sisa).

\section{Pengujian antioksidan}

Ekstrak dan fraksi dari daun pidada merah dibuat larutan baku induk (stok) sebesar 1000 ppm, dari larutan stok dibuat larutan uji dengan 5 seri konsentrasi. Selanjutnya, disiapkan larutan DPPH dengan konsentrasi 40 ppm. Larutan uji dengan berbagai seri konsentrasi sebanyak $2 \mathrm{~mL}$ ditambahkan dengan $2 \mathrm{~mL}$ larutan DPPH 40 ppm dalam tabung reaksi bertutup lalu dihomogenkan dan didiamkan di tempat gelap pada suhu kamar selama 30 menit. Kemudian, dilakukan pengukuran absorbansinya pada panjang gelombang maksimum DPPH yaitu $522 \mathrm{~nm}$ menggunakan Spektrofotometer UV-Visible (Suprianto \& $M$, 2016).

\section{HASIL DAN PEMBAHASAN}

\section{Parameter Spesifik}

Hasil pemeriksaan parameter spesifik yaitu pemeriksaan makroskopik tumbuhan daun pidada merah memiliki rasa pahit, bentuk daunnya bulat telur atau memanjang, ujung daunnya membulat atau tumpul, tepi daunnya rata, susunan tulang daunnya menyirip, warna daunnya hijau tua, dan ukuran daunnya panjang $8,5 \mathrm{~cm}$, lebar $4 \mathrm{~cm}$. Hasil pemeriksaan mikroskopik pada gambar 1. Berdasarkan hasil yang diperoleh diketahui bahwa daun pidada merah memiliki fragmen pengenal seperti jaringan epidermis atas, jaringan epidermis bawah dengan stomatanya, berkas pembuluh, stomata. 


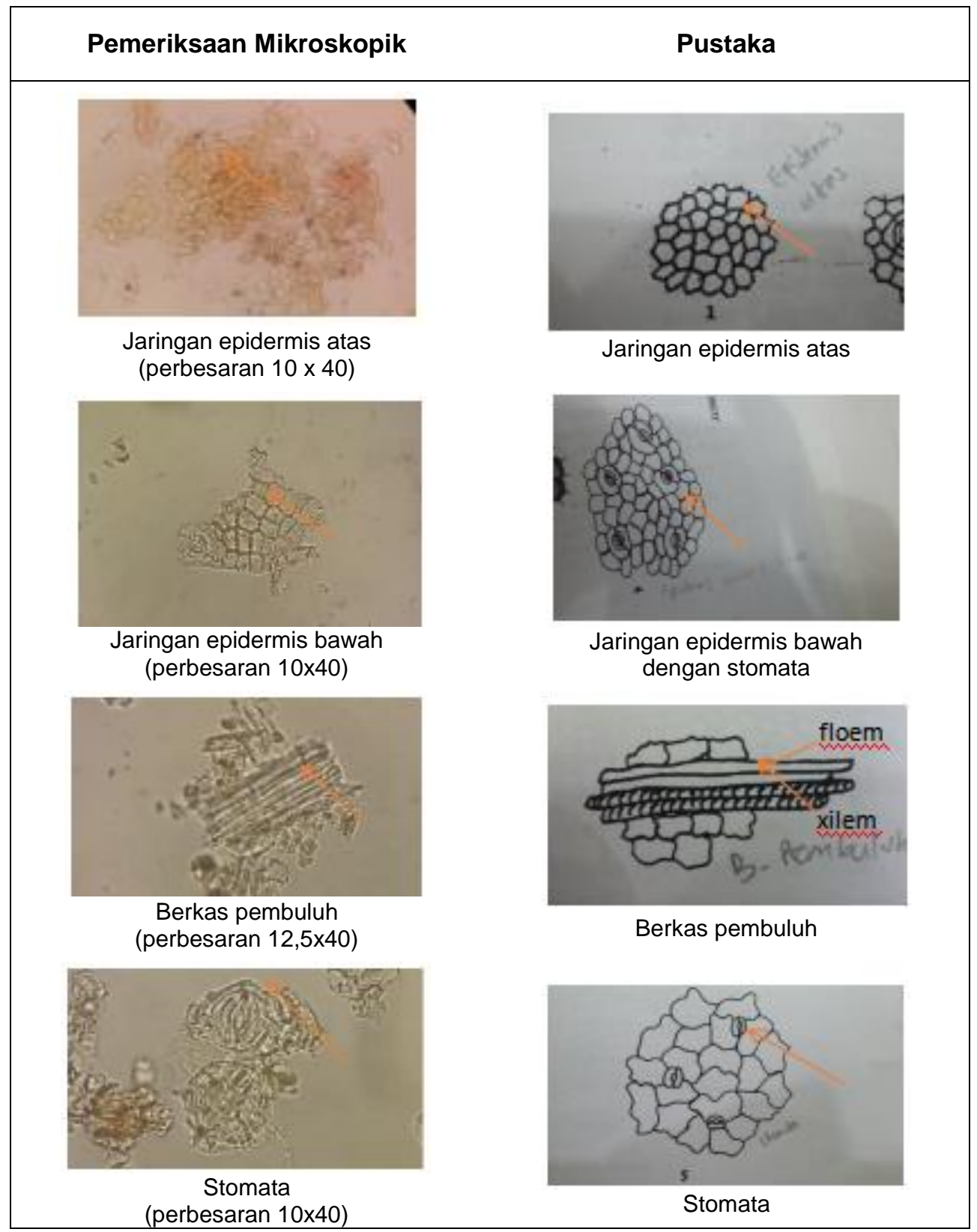

Gambar 1. Hasil pemeriksaan mikroskopik

Berdasarkan Tabel 1 penetapan kadar sari larut air untuk mengetahui kadar senyawa kimia bersifat polar yang terkandung di dalam simplisia, didapatkan hasil sebesar $11 \%$.

Tabel 1. Hasil kadar serbuk simplisia daun pidada merah

\begin{tabular}{cc}
\hline Uji & Kadar (\%) \\
\hline Kadar sari larut air & 11 \\
Kadar sari larut etanol & 16 \\
\hline
\end{tabular}

Kadar sari larut etanol dilakukan untuk mengetahui kadar senyawa larut dalam etanol, baik senyawa polar maupun non polar didapatkan hasil sebesar $16 \%$. Kandungan sari larut air lebih kecil daripada kadar sari larut etanol, ini berarti senyawa kimia lebih larut dalam etanol dibandingkan larut air. Parameter spesifik sudah sesuai dengan ketentuan standar yang ditetapkan oleh literatur dari panduan Kementerian Kesehatan RI (Kemenkes RI, 2020). 


\section{Parameter Non Spesifik}

Berdasarkan tabel 2 penetapan kadar air bertujuan untuk mengetahui kandungan kadar air dalam simplisia. Hasil penetapan kadar air yang diperoleh pada simplisia memenuhi persyaratan yaitu $9 \%$ karena persyaratan yang ditetapkan yaitu kurang dari $10 \%$. Kadar air yang tidak memenuhi persyaratan mengakibatkan pertumbuhan mikroba, karena air merupakan media pertumbuhan mikroorganisme dan juga sebagai reaksi enzimatis yang dapat menguraikan senyawa aktif.

Penetapan kadar abu bertujuan untuk mengetahui kandungan mineral dalam simplisia. Hasil yang diperoleh dari penetapan kadar abu simplisia daun pidada merah yaitu $8,17 \%$. Penetapan kadar abu tidak larut asam bertujuan untuk mengetahui kadar senyawa yang tidak larut asam, misalnya silika, logamlogam berat seperti $\mathrm{Pb}$ dan $\mathrm{Hg}$ (Depkes RI, 1985). Hasil yang diperoleh dari penetapan kadar abu tidak larut asam simplisia daun pidada merah yaitu $0,48 \%$. Nilai Non Spesifik ini sudah sesuai dengan ketentuan standar yang ditetapkan oleh literatur dari panduan Kementerian Kesehatan RI (Kemenkes RI, 2020).
Tabel 2. Hasil kadar serbuk simplisia daun pidada merah

\begin{tabular}{cc}
\hline Uji & Kadar (\%) \\
\hline Kadar air & 9 \\
Kadar abu & 8,17 \\
$\begin{array}{c}\text { Kadar abu tidak larut } \\
\text { asam }\end{array}$ & 0,48 \\
\hline
\end{tabular}

\section{Aktivitas Antioksidan}

Ekstrak dan fraksi daun pidada merah postensi sebagai antioksidan aktivitas antioksidan vitamin C termasuk kategori antioksidan sangat kuat karena nilai $\mathrm{IC}_{50}$ kurang dari 50 ppm (Tabel 3). Menurut Molyneux (2003) nilai IC50 kurang dari 50 ppm termasuk kategori antioksidan sangat kuat. Aktivitas antioksidan vitamin $\mathrm{C}$ pada pengujian ini lebih tinggi, dimana vitamin $\mathrm{C}$ memiliki nilai IC 50 sebesar 7,22 ppm.

Menurut penelitian dari Duke (2006) menyatakan bahwa pada spesies soneratia ini telah dilakukan isolasi ditemukan adanya metabolit sekunder yaitu (-)-(R)-nyasol, (-)-(R)4'-O-metilnyasol dan asam maslinat ketiga senyawa ini menunjukkan aktivitas sitotoksik terhadap tikus glioma garis sel $\mathrm{C} 6$ dengan nilai IC 50 masing-masing 19,02, 20,21 dan 31,71 ppm. Hal ini menunjukkan potensi antioksidan yang tinggi.

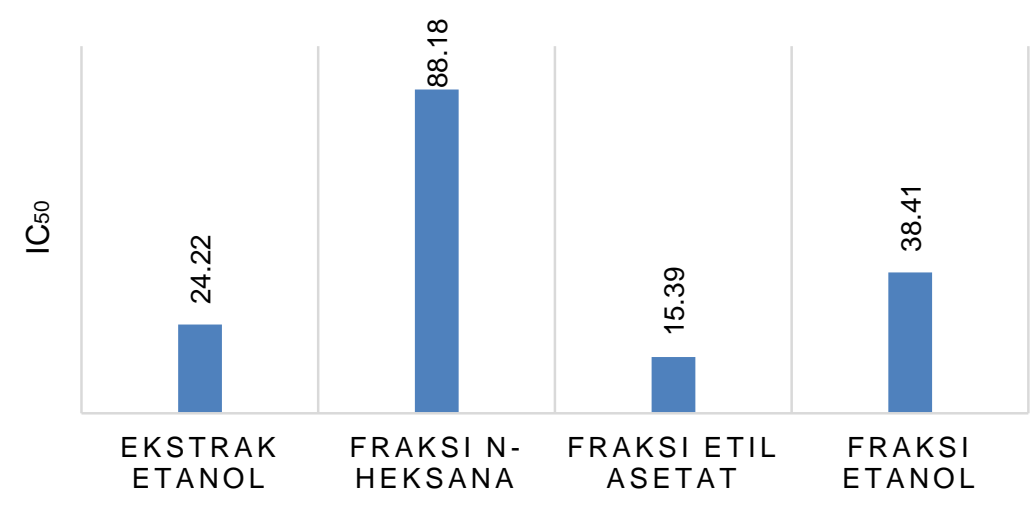

JENIS PELARUT

Gambar 2. Perbandingan nilai $I_{50}$ ekstrak dan fraksi daun pidada merah 
Tabel 3. Hasil pengujian antioksidan ekstrak dan fraksi daun pidada merah

\begin{tabular}{|c|c|c|c|c|}
\hline Jenis & ppm & IC & Persamaan & $\mathrm{IC}_{50}$ \\
\hline \multirow{5}{*}{ Ekstrak Etanol } & 10 & 30,9987 & \multirow{5}{*}{$\begin{array}{c}y=1,3732 x+16,959 \\
r^{2}=0,9953\end{array}$} & \multirow{5}{*}{24,06} \\
\hline & 20 & 43,0053 & & \\
\hline & 30 & 60,3477 & & \\
\hline & 40 & 70,5206 & & \\
\hline & 50 & 85,8995 & & \\
\hline \multirow{5}{*}{ Fraksi n-Heksana } & 25 & 14,3828 & \multirow{5}{*}{$\begin{array}{c}y=0,5631 x+0,3444 \\
r^{2}=0,9902\end{array}$} & \multirow{5}{*}{88,18} \\
\hline & 50 & 30,7459 & & \\
\hline & 75 & 40,4044 & & \\
\hline & 100 & 54,4105 & & \\
\hline & 125 & 72,9366 & & \\
\hline \multirow{5}{*}{ Fraksi Etil Asetat } & 5 & 19,7376 & \multirow{5}{*}{$\begin{array}{c}y=3,0502 x+3,0375 \\
r^{2}=0,9943\end{array}$} & \multirow{5}{*}{15,39} \\
\hline & 10 & 32,1687 & & \\
\hline & 15 & 49,1271 & & \\
\hline & 20 & 61,689 & & \\
\hline & 25 & 81,2336 & & \\
\hline \multirow{5}{*}{ Fraksi Etanol } & 10 & 19,7376 & \multirow{5}{*}{$\begin{array}{c}y=1,1151 x+7,1583 \\
r^{2}=0,9891\end{array}$} & \multirow{5}{*}{38,41} \\
\hline & 20 & 41,1687 & & \\
\hline & 30 & 55,2309 & & \\
\hline & 40 & 73,689 & & \\
\hline & 50 & 87,2336 & & \\
\hline \multirow{5}{*}{$\begin{array}{l}\text { Pembanding } \\
\text { (Vitamin C) }\end{array}$} & 5 & 34,5419 & \multirow{5}{*}{$\begin{array}{c}y=6,2443 x+4,935 \\
r^{2}=0,9519\end{array}$} & \multirow{5}{*}{7,22} \\
\hline & 7,5 & 48,7404 & & \\
\hline & 10 & 71,6412 & & \\
\hline & 12,5 & 90 & & \\
\hline & 15 & 91,9656 & & \\
\hline
\end{tabular}

Dari ke empat sampel uji, fraksi etil asetat memiliki aktivitas antioksidan yang paling baik jika dibandingkan dengan ekstrak etanol, fraksi nheksana, dan fraksi etanol karena memiliki nilai $\mathrm{IC}_{50}$ (konsentrasi penghambatan $50 \%$ radikal) terkecil yaitu 15,39 ppm (Gambar 2). Menurut penggunaan obat tradisional tumbuhan Perepat Merah, diketahui memiliki kandungan senyawa bioaktif seperti flavonoid, steroid, fenol hidrokuinon, tanin dan dua flavonoid yaitu luteolin dan luteolin 7-O- $\beta$ glukosida (Sadhu et al., 2006). Menurut penelitian Yushar (2011) pada spesies Sonneratia alba mengandung tanin, steroid, fenol, dan saponin.

\section{KESIMPULAN}

Hasil karakterisasi simplisia yaitu: kadar sari larut air $11 \%$, kadar sari larut etanol $16 \%$, kadar air 9\%, kadar abu 8,17\%, dan Kadar abu tidak larut asam $0,48 \%$. Hasil penelitian menunjukkan bahwa ekstrak dan fraksi daun pidada merah memiliki aktivitas antioksidan, yaitu ekstrak etanol memiliki nilai $I_{50} 24,22$ ppm (sangat kuat), fraksi n-heksana 88,18 ppm (kuat), fraksi etil asetat 15,39 ppm (sangat kuat), dan fraksi etanol 38,41 ppm (sangat kuat) 


\section{UCAPAN TERIMAKASIH}

Tim Peneliti mengucapkan terimakasih kepada Direktorat Riset dan penagbdian masyarakat Kementrian Riset dan Teknologi Badan Riset dan Inovasi nasional atas pendanaan pada penelitian ini pada Skim Penelitian Terapan dengan nomer kontrak SPPK: $\quad$ 191/SP2H/AMD/LT/DRPM/2019 Tanggal 12 November 2019.

\section{DAFTAR PUSTAKA}

Avenido, P. edro, \& Serrano Jr, A. (2012). Effects of the apple mangrove (Sonneratia caseolaris) on growth, nutrient utilization and digestive enzyme activities of the black tiger shrimp Penaeus monodon postlarvae. European Journal of Experimental Biology, 2: 1603-1608.

Depkes RI. (1985). Cara Pembuatan Simplisia. Departemen Kesehatan RI, Jakarta, hal. 2-15.

Duke, N. (2006). Australias Mangroves The Autoritative Guide to Australias Mangrove Plants. University of Queensland, Brisbane, hal. 200.

Jubaidah, S., Sundu, R., \& Sabriningsih, N. (2019). Penetapan Kadar Fenolik Total Fraksi Polr Dan Nonpolar Daun Rambai Laut (Sonneratia caseolaris L.) Dengan Metode Spektrofotometri UV-Vis. Jurnal Riset Kefarmasian Indonesia, 1(2): 140147. https://doi.org/10.33759/jrki.v1i2.23

Kemenkes RI. (2020). Farmakope Herbal Indonesia Edisi VI. Kementerian Republik Indonesia, Jakarta.

Molyneux, P. (2003). The use of the stable radical Diphenylpicrylhydrazyl (DPPH) for estimating antioxidant activity. Songklanakarin J. Sci. Technol. 26 (2): 211-219.

Nurmalasari, F., Ersam, T., \& Fatmawati, S. (2016). Isolasi Senyawa Antioksidan Dari Kulit Batang Sonneratia Ovata Backer. Jurnal Sains dan Seni ITS, 5(2). https://doi.org/10.12962/j23373520.v5i2.1 9484
Sadhu, S. K., Ahmed, F., Ohtsuki, T., \& Ishibashi, M. (2006). Flavonoids from Sonneratia caseolaris. Journal of Natural Medicines, 60(3): 264-265. https://doi.org/10.1007/s11418-006-00293

Sosio, Yudasakti, P., Rahmadhani, T., \& Nainggolan, M. (2014). Mangroves Siak \& Kepulauan Meranti. Energi Mega Persada, Jakarta, hal. 21-23.

Suprianto, H., \& M, M. A. (2016). Aktivitas Ekstrak Dan Fraksi Daun Pidada Merah (Sonneratia caseolaris L.) Sebagai Antioksidan. PROSIDING SEMINAR KIMIA 2013, hal. 164-169. http://jurnal.kimia.fmipa.unmul.ac.id/index .php/prosiding/article/view/116

Wijaya, H., Novitasari, N., \& Jubaidah, S. (2018). Perbandingan Metode Ekstraksi Terhadap Rendemen Ekstrak Daun Rambai Laut (Sonneratia caseolaris L. Engl). Jurnal Ilmiah Manuntung, 4(1): 7983.

Yushar, A. D. (2011). Ekstraksi dan Uji Fitokimia Sonneratia alba. Universitas Padjajaran, Bandung. (diunduh pada https://www.academia.edu/7344560/EKS TRAKSI_DAN UJI_FITOKIMIA Sonnera tia_alba?auto=download). 